Review Article

\title{
Flowers and gardens on the context and tourism potential
}

\author{
Patrícia Duarte de Oliveira Paiva ${ }^{1 *}$, Rafael de Brito Sousa ${ }^{1,2,3}$, Nathalie Carcaud ${ }^{3}$
}

\begin{abstract}
Travel and Tourism have been considered one of the world's largest economic sectors, and garden visiting has been suggested as an important segment (niche) on the tourism industry. In this context, the aim is to analyze gardens as a great potential for tourism, in their different specificity. For tourism, all kinds of greenspaces may be used as historic, botanical or private gardens, and parks, besides events as garden and flower festival and exhibitions. All of them are responsible for attracting many visitors. This type of tourism has been increasing since tourists are eager for new and unique experiences that contribute to the memory and the identity of a nation and gardens may allow this to happen.
\end{abstract}

Keywords: landscaping, historic gardens, flower show, botanical gardens.

\section{Resumo}

\section{Flores e jardins como contexto e potencial turístico}

Viagens e turismo são considerados um dos grandes setores econômicos, sendo a visita aos jardins sugerida como importante segmento (nicho) na indústria do turismo. Nesse contexto, o objetivo foi analisar os jardins como grande potencial para turismo, nas suas diferentes especificidades atuais. Para turismo, todos os tipos de áreas verdes podem ser usados como jardins históricos, parques, jardins botânicos, jardins particulares, além de eventos como festivais de flores e jardins e exposições. Todos são responsáveis por atrair muitos visitantes. Esse tipo de turismo tem aumentado, pois turistas estão ávidos por novas e únicas experiências que contribuem para a memória e identidade de um povo, e jardins proporcionam isso.

Palavras-chave: paisagismo, jardins históricos, feiras, jardins botânicos.

\section{Introduction}

Tourism involves a combination of travel, destination, and marketing, leading to a process in the cultural dimension (UNWTO, 2020). Travel and Tourism are considered one of the world's largest economic sectors, supporting more than 300 million jobs. This represents 1 in 10 jobs worldwide, generating $10.4 \%$ of world Gross Domestic Product (GDP), including directly, indirectly, and induced impacts. In 2018, Travel and Tourism raised $3.9 \%$ compared with $3.2 \%$ of the global economy (WTTC, 2019). The USA received the greatest contribution to GDP from Travel and Tourism, $19 \%$, considering the direct impact, but China is seeking to have this position in 2028 (Nicol and Jukes, 2018).

The tourism matrix has changed over the years and now is characterized as an "industry of experiences" (Silva et al., 2013). Tourists have been looking for new and unique experiences. Thus, they seek to live and feel sensations and experiences of the places, to experience moments in a remarkable way, and seeking for everything that may be different and that goes beyond common sense (Silva et al., 2013). Different from traditional tourism, some new categories are getting importance in the latest years, most of them related to nature and environment such as Geotourism, Bird watching, Hunting, Wine tourism, Ecotourism, Cruise lines, Archaeological, University tourism, Gastronomic tourism, Religious tourism, Volunteering, Hot air ballooning, Ethnic tourism, Sports tourism, Routing Tourism, Health and Wellness tourism, Bike tourism and Routes, and Garden tourism.

The environment represents $45 \%$ on total city tourism. Considering its components, Natural Resources corresponds to 53\%, which include Parks (14\%), Botanical Garden $(18 \%)$, water bodies with recreation and tourism structure (13\%), others (28\%) (Cibinskiene and Snieskiene, 2015). Gardens express the relation from humans and

\footnotetext{
${ }^{1}$ Universidade Federal de Lavras, Departamento de Agricultura, Lavras-MG, Brazil *Corresponding author: patriciapaiva@ufla.br

${ }^{2}$ Université d'Angers (UA), Angers, France

${ }^{3}$ UMR ESO - Agrocampus Ouest, Angers, France
}

Received Jan 26, 2020 | Accepted Mar 18, 2020| Available online Mar 30, 2020 
nature, transcending culture, time and place (Doolittle, 2004), and due that, are among the most outstanding tourist attractions (Silva and Carvalho, 2013).

Garden tourism or garden visiting has been suggested as an important segment (niche) on the tourism industry in postmodernity (Connell, 2004), involving not only the travel but also the visit to different kinds of gardens, not only the famous ones. Demand for visiting gardens and landscapes have shown an increase, based on the characteristics of these sites for what they evoke, symbolize, and represent (Backhaus and Murungi, 2009). A garden touristic visit, besides to promote and increase a stay period on many destinations, may also contribute to nature preservation, improve an ecological conscience, exciting visitors to appreciate the natural world, and increase income which may use for preservation of the sites (Gastal et al., 2018a). Gardens and landscapes are spaces of various sensorial and visual sensations, as well as a way to offer visitors several activities or opportunities for contemplation or just, to be on it (Silva et al., 2013).

\section{Garden tourism or garden visiting}

Gardens are a living monument, a reflex of culture and history of one community or nation (Carta de Florença, 1981). Everywhere in the world, gardens have always been a space of innovation (Claval, 1989). Each garden is unique, being a witness from history and an important cultural document source (Andrade, 2008). Since the Renaissance, the art of gardens has been considered as "Third Nature" which is built from the "First Nature" (natura naturans) due to the knowledge and work of the "Second Nature" (natura naturata), from the human's work (Bennetiere, 2000).

Most of the gardens in the past are not created with the aim of tourism, or for attracting visitors. They were built by private owners to embellish their property (Connell, 2005). Only over the years, by acquiring historic importance is that these spaces were discovered by researches, visitors and nature lovers .

Besides any kind of garden may turn into a touristic attraction, in Europe, some gardens may receive the distinction of Remarkable Garden, either those open to public, protected or not by law. These also include those with monuments and sites of national importance that present great historic, aesthetic, or botanical interest (MCC, 2012). The preferable remarkable gardens for visiting are those with designed gardens and that allows users to photograph (Brigand, 2015). Although this is not enough to attract visitors, some other actions are important. The attractiveness may be due to the use of a public label of quality or to have a governmental label as "Remarkable Garden". As an example of a gardens' demonstration, in France there is the «Rendez-vous aux Jardins" event which corresponds to an annual event organized by the Ministry of
Culture and Communication, in association with Parks and Gardens Committee and take place on the first weekend of June (Rendez-vous aux Jardins, 2020).

Communication is another important issue and websites are encouraged to have a specialized press and professional social media. Another interesting activity is to host events such as Garden Open Days, awards and prizes for professionals; training and education, lectures, culture festivals (such as music, arts), and sport events (running, yoga, and others). Development of a planning template for garden management, involving gardeners, students, and garden lovers is another good practice. In a technical view, a good suggestion is the creation of a botanical inventory, and let it available on the internet (Brigand, 2015).

\section{Understanding touristic attractions}

The tourist attraction is "a system including three elements: a tourist or human element, a nucleus or central element, and a marker or informative element, and modeled the relationships between these three elements" (Leiper, 1990). Heritage Visitor Attractions (HVA) are related to Cultural heritage tourism which involves visiting places that are significant to the past or present cultural identity of a particular group of people (McNulty and Koff, 2014). These sites include cultural, historic and natural resources, with the visitors lead to experience the places, objects and perform activities. Some of these places may be considered as a World Heritage Site (WHS), "the designation for places on Earth that are of outstanding universal value to humanity and such, have been inscribed on the World Heritage List to be protected for future generations to appreciate and enjoy" (UNESCO, 2020).

The Heritage visitor experience may be analyzed in three stages: pre, in situ and post visitation. Prior the visit, tourists have some motivations leading to the expectation of having a meaningful experience and the information based on decision making. In this phase, advice from friends and relatives is very important despite social media (Kempiak et al., 2017). During the in situ visitations, the information, communication, engagement, and atmosphere are important points. In a post visitation, the visitors value the duration, knowledge acquisition, and generate a level of satisfaction that may stimulate a re-visitation on other occasions (Kempiak et al., 2017).

Heritage tourism is "the movement of persons to cultural attractions away from their normal place of residence, with the intention to gather new information and experiences to satisfy their cultural needs" (Richards, 2001). Natural heritage experience is motivated by the search of knowledge, learning, and entertainment (Poria et al., 2004) which is provided by the natural and cultural heritages.

One important characteristic to consider for heritage visitors is that younger is the smallest group. The majority of the visitors has completed higher education and tends to have more polite behavior (Kempiak et al., 2017). 


\section{Garden tourism origins}

Garden Visit is an activity mainly registered from the $20^{\text {th }}$ and $21^{\text {st }}$ centuries; there are some historic registers from the $16^{\text {th }}$ century. Visiting gardens started on Great Britain before the early Victorian period (18301848) when people from the upper class used to visit country houses (Connel, 2003). It was also in $16^{\text {th }}$ that some aristocrats, politicians and other financially wealthy Englishmen started to build some country houses and gardens for pleasure (Connel, 2003).

Michel de Montaigne, an important philosopher of the French Renaissance on $16^{\text {th }}$ century, was the first garden tourist to make registrations about his impressions of gardens, in a publication from 1580, "Essais" (Michel de Montaigne, 2020).

Louis XIV, a garden lover, wrote in the $17^{\text {th }}$ century, a guide for visiting Versailles' gardens, untitled "Manière de Montrer les Jardins de Versailles" (Louis XIV, 2013). This guide reflects his personnel vision of an amazing garden, detailing the perspectives and places. It was written by his own hand and is considered as a Royal Law.

During the $18^{\text {th }}$ century, garden ideas were diffused and stimulated for foreign and domestic travelers eager to see the landscapes by themselves (Connell, 2005). Only at the end of the $19^{\text {th }}$ century, John Evelyn (16201706), a writer and garden lover, use to register on his diary, details of visits performed to gardens in Italy and France, including tree descriptions (Evelyn, 2020).

The effective garden tourism started in 1927, in England, with the foundation of the National Garden Scheme. In this initiative, more than 3500 private gardens in England and Wales are opened for public visitation on selected dates for charity in the event Gardens of England and Wales Open for Charity. The gardens participants are vetting by the organizers and should have quality, character and raise the interest by the public that also visit for charity (McMillan and Plumptre, 2019).

All the information about the gardens are published in "The Garden Visitor's Handbook" (formerly the Yellow Book). The current patron is Charles, Prince of Wales, and the money raised is used to support The Queen's Nursing Institute, Marie Curie, Hospice UK, Macmillan Cancer Support, and others (McMillan and Plumptre, 2019).

Due to the way of life nowadays, with people living in crowded cities, the need for greenspaces such as parks, botanical gardens, historic gardens, and others, has been increased, turning these spaces more and more valuable (Gastal et al., 2018a).

\section{In the search for a lost Paradise...}

\section{The Garden visit experience}

The interest in visiting gardens has increased since this type of tourism encourages integration into space. Also, gardens provide the visitors' new experiences, discoveries, and the sensation of being included in the daily life of the destination, besides the offering of knowledge and learning.

Motivations for visiting a garden are diverse as it corresponds to a multidimensional landscape. Visitors have diverse aspirations including the aim of observing rare qualities and aesthetics from some specific ornamental plants; interests for the garden design; highlighted interest in history and culture; nostalgia; curiosity and education; interests in learning techniques used during different periods over the time; pleasure in scenery contemplation; feel the environment and garden atmosphere; entertainment; spiritual values; looking for peace, tranquility, and freedom of the garden area; get inside and have the garden essence to human well-being, healthy, psychology, and physical equilibrium; possibility of socialization by meeting family and friends; visiting to know architects, gardeners and landscapists famous work (Connell, 2005; Silva et al., 2013; Kempiak et al., 2017; Gastal et al., 2018a).

For raising a garden visit, it is important to provide adequate physical structure. In a research to identify the preferences of English visitors, it was found to be very important in the place the presence of toilets and car parking (Connell, 2004). It is also considered as important the availability of plant sales, tea rooms, and guide-book. However, it was not considered as important to have shops, guided walks, events, as well as children's area (Connell, 2004). This kind of information is interesting to guide the garden's owner. Motivations for opening a site for visitation include a desire to improve and also to provide tastes, impressions, knowledge, and to raise the aspirations of the visitors.

Gardens assemble natural, cultural and historic components and have a unique history, providing a singular experience for the visitors. Furthermore, it is an important source of historic documents from a culture, a place and a time. Garden tourism includes visits to many different places as historic gardens, botanic gardens, and participation on events related to ornamental plants and garden supplies or, simply, to visit city parks and squares (Silva et al., 2013). Indeed, this type of tourism is performed by visitors in their home area or by others that are traveling in short or long distances, either abroad, with the aim of visiting a specific place (Gastal et al., 2018a).

There are several important and famous gardens around the world that attract millions of visitors, as Botanical Gardens, Historic Gardens, or Modern/Contemporary Parks, with some of them being listed on the Unesco World Heritage List (Table 1). 
Table 1. Main gardens in the world and number of visitors .

\begin{tabular}{|c|c|c|c|c|}
\hline Garden & Location & $\begin{array}{l}\text { Visitors } \\
\text { (per year)* }\end{array}$ & Type** & $\begin{array}{l}\text { World Heri- } \\
\text { tage List*** }\end{array}$ \\
\hline Central Park & New York/USA & 38.0 million & $\mathrm{M} / \mathrm{CG}$ & - \\
\hline Chateau de Versailles & Versailles/France & 10.0 million & HG & $\mathrm{C}$ \\
\hline Peterhof Palace & St. Petersburg/Russia & 5.3 million & HG & $\mathrm{C}$ \\
\hline Tivoli Gardens & Copenhagen/Denmark & 4.0 million & $\mathrm{M} / \mathrm{CG}$ & - \\
\hline Botanic Garden Inhotim & Brumadinho/Brazil & 3.0 million & BG & - \\
\hline Alhambra Palace & Granada/Spain & 2.4 million & HG & $\mathrm{C}$ \\
\hline Royal Botanic Gardens at Kew & Richmond/England & 2.1 million & BG & $\mathrm{C}$ \\
\hline Palace and Gardens of Schönbrunn & Vienna/Austria & 2.0 million & HG & $\mathrm{C}$ \\
\hline Longwood gardens & Kennett Square/USA & 1.5 million & $\mathrm{M} / \mathrm{CG}$ & - \\
\hline Butchart Gardens & Victoria/Canada & 1.0 million & $\mathrm{M} / \mathrm{CG}$ & - \\
\hline Missouri Botanical Garden & St. Louis/USA & 1.0 million & BG & - \\
\hline $\begin{array}{l}\text { Royal Exhibition Building and Carlton } \\
\text { Gardens }\end{array}$ & Melbourne/Australia & 800,000 & $\mathrm{M} / \mathrm{CG}$ & $\mathrm{C}$ \\
\hline Gardens of Temple Bahai & Haifa/Israel & 750,000 & HG & - \\
\hline Suan Nong Nooch Garden & Pattaya/Thailand & 730,000 & BG & - \\
\hline Nikita Botanical Garden & Yalta/Russia & 700,000 & BG & - \\
\hline Claude Monet's Garden & Giverny/France & 627,000 & HG & - \\
\hline Gardens of Jacques Majorelle & Morroco & 500,000 & HG & - \\
\hline Villa d'Este & Tivoli/Italy & 500,000 & HG & $\mathrm{C}$ \\
\hline Château Villandry & Loire Valley/France & 350,000 & HG & $\mathrm{C}$ \\
\hline Terra Botanica & Angers/France & 280,000 & BG & - \\
\hline Botanic Garden - Rio de Janeiro & Rio de Janeiro/Brazil & 150,000 & BG & - \\
\hline Dumbarton Oaks & Washington/USA & 30,000 & $\mathrm{M} / \mathrm{CG}$ & - \\
\hline The Master-of-Nets Garden & Suzhou/China & Not available & HG & - \\
\hline $\begin{array}{l}\text { Gardens of the Villa Éphrussi de Roth- } \\
\text { schild }\end{array}$ & St. Jean-Cap-Ferrat/France & Not available & $\mathrm{HG}$ & - \\
\hline Koishikawa Korakuen & Tokyo/Japan & Not available & HG & - \\
\hline Rikugien Gardens & Tokyo/Japan & Not available & $\mathrm{HG}$ & - \\
\hline Schloss Mirabell and Mirabell Gardens & Salzburg/Austria & Not available & $\mathrm{HG}$ & - \\
\hline
\end{tabular}

\section{Botanical Gardens}

Botanical garden is "an institution holding documented collections of living plants for the purposes of scientific research, conservation, display and education" (Wyse Jackson, 1999), and this is the real function nowadays, differently from the beginnings, when botanic gardens were defined as 'places open to the public and in which plants were labeled' (Powledge, 2011).
The existence of botanical gardens dates back from the $15^{\text {th }}$ century when plant species from the new world brought by the great navigations on their return to Europe, were planted and maintained in protected places to ensure their survival and propagation (Rocha and Cavalheiro, 2001). Some other botanical gardens were built to support teaching in medical schools, with botany classes focused on pharmacist and surgeons (Camargo, 2007). These 
early gardens were located in Italy; Pisa (1543), Padova (1545), and Florence (1550); Germany; Leipzig (1580); Netherlands: Leiden (1590), and in France; the Montpellier Botanical Garden (1593) (Krishnan and Novy, 2016; Montpellier, 2020).

Since the early $19^{\text {th }}$ century, the interest in gardening and botany increased and some cities started to create their own botanical garden. Due that, the number of botanic gardens has grown remarkably worldwide in the latest years (Edwards and Wyse Jackson, 2019). There are not a defined number of botanical gardens in the world, but the Botanic Gardens Conservation International (BGCI) leads the Global Strategy on Plant Conservation (GSPC), and its database (https://www.bgci.org/garden_search. php) currently holds information on over 3,571 botanical institutions worldwide.

The number of visitors per year attracted by the world's botanical gardens is around 500 million. Besides this, there are indications for actions to expand public engagement in activities that are the expertise of the botanical gardens as science, conservation, and sustainability connected to environmental issues, such as food security, energy, health, loss of biodiversity and climate changes (Smith, 2018).

Botanical Garden should be considered and treated as a living museum since beyond the collections, stands as a source of natural and cultural histories and symbologies. Thus, there is an important educational issue for visitors and local communities, as well as being attractive for outdoor activities, allowing qualified leisure, and people closer to nature (Gastal et al., 2018b).

Botanical Gardens include structures for plant science and research activities with exotic and native plant living collections, including seeds and tissues. Example of research activities includes plant cultivation for biodiversity conservation; plant management in the wild and natural habitats, species for ecological restoration, and recovery (Edwards and Wyse Jackson, 2019). Furthermore, botanical gardens hold programs in public education, strengthening connections with local communities, including social inclusion as well as public relaxing and recreation (Edwards and Wyse Jackson, 2019; Heywood, 2017). Most people nowadays, special in big cities, have a way of life aside and disconnected from their natural world and botanical gardens can play a major role in reconnecting them with nature (Krishnan and Novy, 2016).

In the public view, visiting a Botanic Garden is a way to stay in contact with nature, besides it is a reserved and special place of the environment, an oasis that gives people a daily escapade. In this place, visitors may find tranquility, fresh and clean air, a place to rest with natural beauty and peace, allowing them to relax (Gastal et al., 2018b).

For the future, is expected that botanic gardens may become more specialized, presenting higher interaction with other urban greenspaces improving connections, attending demands of the local community, besides allowing public recreation, horticultural practices, plant research and education, and outreach (Krishnan and Novy, 2016; Heywood, 2017). Another issue is the development of strategic marketing and management policies, enhancing visitor experience with limited resource allocation, ensuring to be a sustainable business, avoiding lacking such provision and resources (Catahan and WoodruffeBurton, 2018).

Nowadays, some botanical Gardens have important collections and Research Centers attracting many visitors as Kew Gardens, Rio de Janeiro Botanical Garden, Nikita Botanical Garden, and Inhotim Botanical Garden (Figure 1), among many others worldwide.

In a world of a growing population, there is a tremendous opportunity and a growing global necessity to expand the role of botanical gardens for beyond their plant diversity and conservation research, strengthening studies in sustainable agriculture, addressing agricultural impacts on natural biodiversity and to advance public understanding of both (Miller, 2015). 

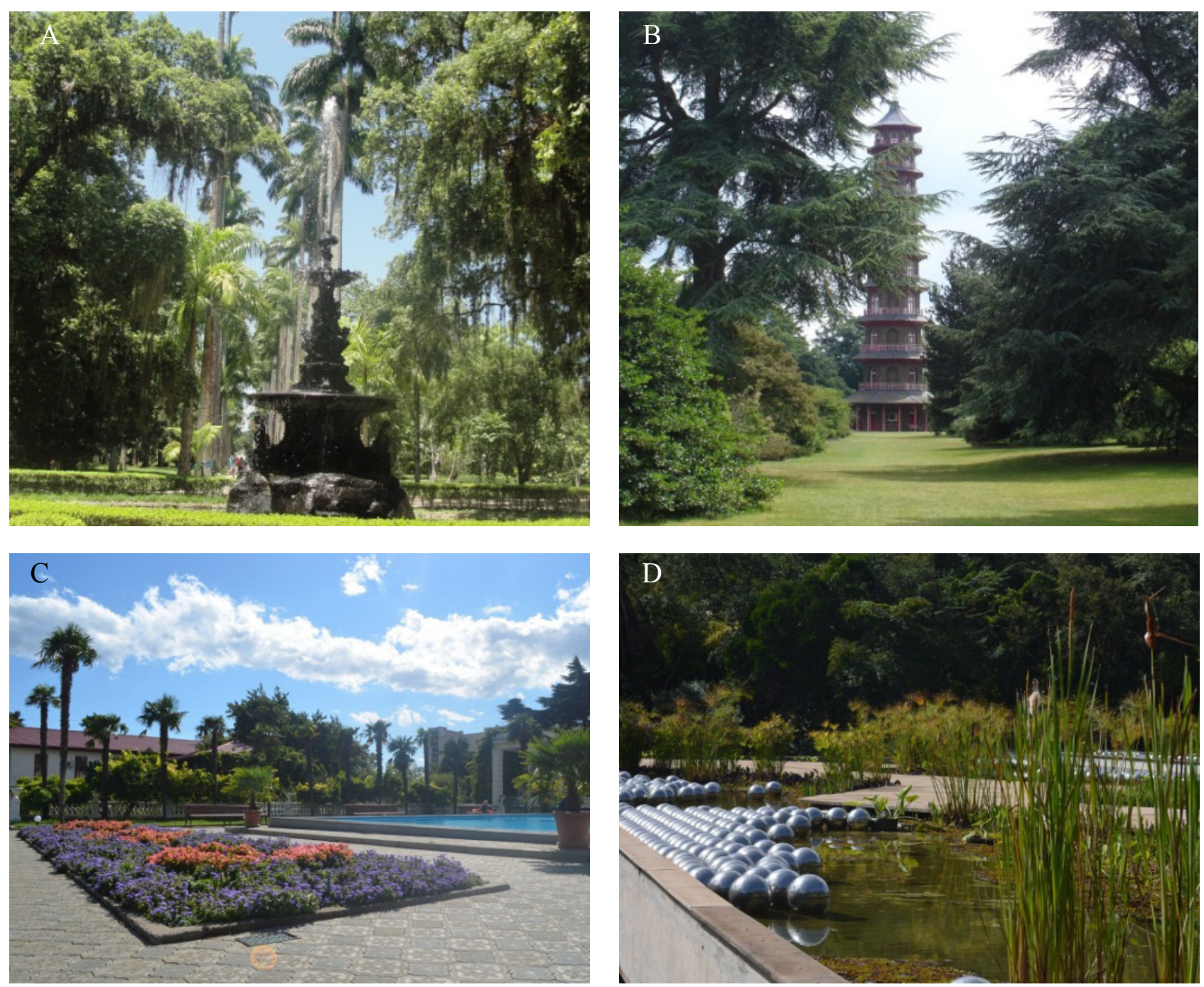

Figure 1. A) Botanical Garden of Rio de Janeiro (Brazil). B) Royal Botanical Garden at Kew (England).

C) Nikita Botanical Garden (Russia). D) Inhotim Botanical Garden (Brazil)

\section{Historic Gardens}

In Persian, garden means Pardis or paradise, and due to this meaning, some historic gardens were destroyed and rebuild, or new gardens have been built generation after generation, turning into important places for visiting around the world (Fallahi, 2017; Fallahi et al., 2019). Many other gardens were built influenced by classic and important styles, like the Persian garden and its Chahar bagh (= quadrilateral garden) concept (Fallahi et al., 2019) and many other different styles (Paiva, 2008).

Historic gardens are defined by the Florence Charter as "an architectural and horticultural composition with interest to the public from the historical and artistic view and that should be considered as a monument" (ICOMOS, 1982). A historic garden receives this identification due to its historical interest, independent of the dimension, according to the Florence Charter (ICOMOS, 1982). Also, historic gardens present bonds with natural heritage and the strongest linkages with life in cities (Andrade, 2008). Considering the cultural heritage and landscape, gardens are essential elements, since they allow great tourism potential, are attractive structures and the site are imbedded or specific elements that identifies the place.

Some gardens are labeled by the UNESCO as World Heritage, like the Royal Exhibition Building and Carlton Gardens (Australia), Palace and Gardens of Schönbrunn (Austria), Classical Gardens of Suzhou (China), and Kew Gardens (Great Britain) (Gastal et al., 2018b). Some of the most visited gardens worldwide are the World Heritage Site as the Palace and Gardens of Alhambra (Granada/ Spain), a palace and fortress complex built by the Nasrid dynasty (1238-1492), surrounded by gardens in Persian style; the Palace and Gardens of Versailles (France, 16611780) and Peterhof (Russia, 1714-1756), both of them built in classical French Style. Regarding the Italian style, Villa D'Este is a very important garden (Figure 2). 

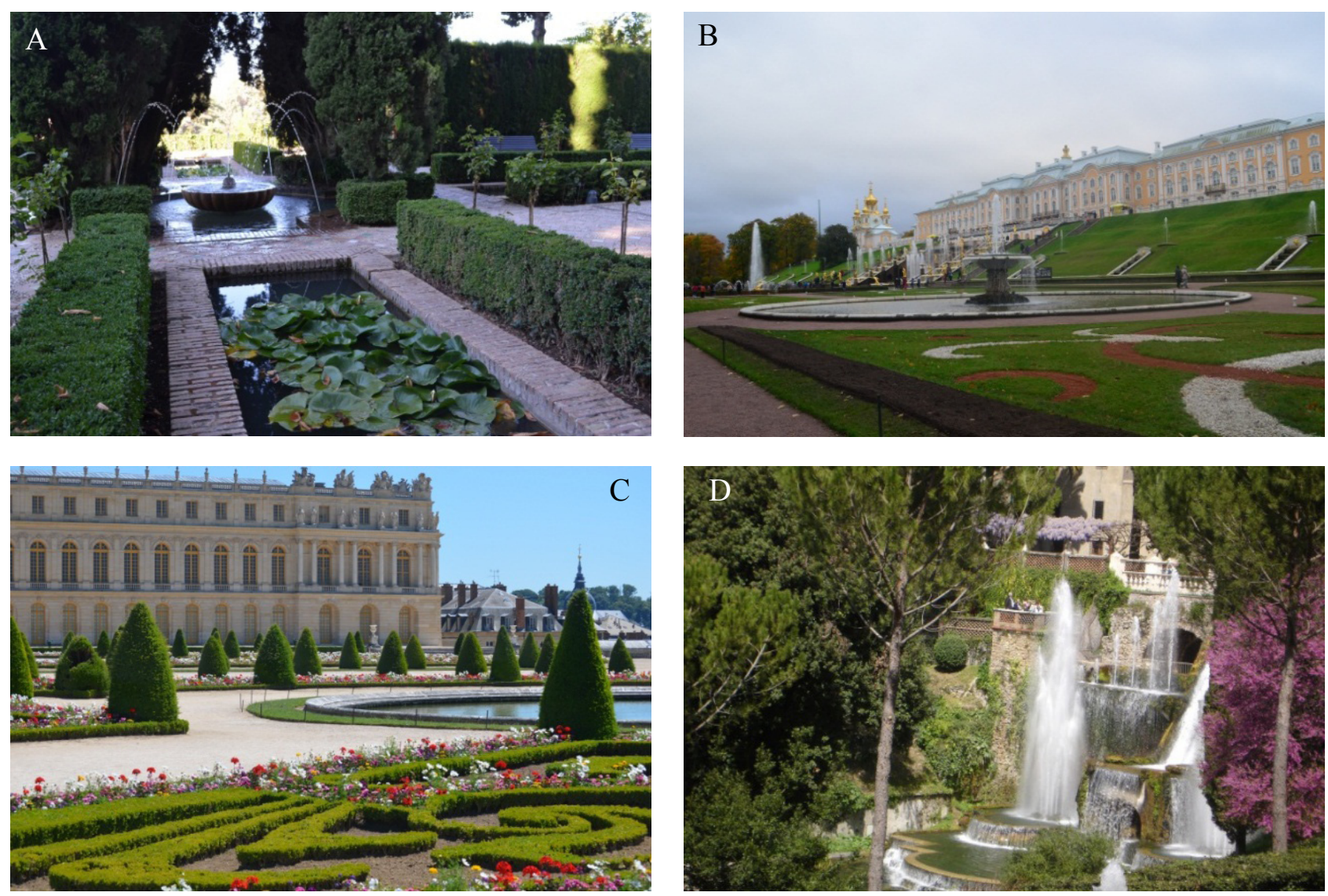

Figure 2. Historic Gardens. A. Alhambra Palace (Spain). B. Peterhof Palace (Russia). C. Versailles Gardens and Palace (France). D. Villa D'Este (Italy)

In the historic gardens, more than flowers and flavors, there are many histories and facts involved (Paiva and Alves, 2011; Garcia and Paiva, 2017). Research developed in Brazil on the history of squares in historical cities, not only documental sources were used. People interview turned able to register facts and events of their memories. In the end, some brochures were written, mainly destined to spread knowledge and history for visitors (Alves et al., 2010; Garcia et al., 2011; Luz and Paiva, 2017; Nascimento and Paiva, 2017; Sousa et al., 2017).

\section{Modern/Contemporary Gardens}

Visits to Modern and or Contemporary gardens are often performed to get to know about some special attractions as the oeuvre of a famous architect or landscapist. For example, special visits have been performed to know the preserved gardens designed by Roberto Burle Marx, mainly those located in the Rio de Janeiro city (Brazil).
Other reasons are those related to entertainment and educational practices. For example, the Inhotim Botanic Garden (Brumadinho/Brazil), besides its plant collections, has many galleries and halls with modern/contemporary artwork exhibitions (https:/www.inhotim.org.br/inhotim/ arte-contemporanea/).

\section{Events and Exhibitions}

Other activities related to gardens and ornamental plants that attract millions of visitors are the events and exhibitions (Table 2). In exhibitions, gardens are shown as culture and experimentation places attracting many visitors' interest on novelties and new tendencies.

For each event or exhibition, a specific theme is chosen which may include social care, ecological conservation, religious morality, perception of life, among others, being supported by companies and or self-organizers. 
Table 2. Main flower and garden events worldwide

\begin{tabular}{|l|c|c|c|}
\hline Garden & Location & Period & $\begin{array}{c}\text { Visitors } \\
\text { (per event)* }\end{array}$ \\
\hline $\begin{array}{l}\text { National Garden Show - Bundesgar- } \\
\text { tenschau (BUGA) }\end{array}$ & Germany & Apr-Oct & 2.5 million \\
\hline Keukenhof Park & Lisse/ The Netherlands & Mar-May & 1.5 million \\
\hline Singapore Garden Festival & Singapore & April-May & 600,000 \\
\hline $\begin{array}{l}\text { International Garden festival - } \\
\text { Chaumont-sur-Loire }\end{array}$ & Chaumont-sur-Loire/ & France & 400,000 \\
\hline Expoflora & Holambra/Brazil & Aug-Sep & 342,000 \\
\hline Chelsea Flower Show & England & May & 157,000 \\
\hline $\begin{array}{l}\text { Festival Internacional de Jardins }- \text { Ponte } \\
\text { de Lima }\end{array}$ & Ponte de Lima/Portugal & May-Oct & 100,000 \\
\hline $\begin{array}{l}\text { Epcot International Flower \& Garden Fes- } \\
\text { tival }\end{array}$ & Orlando/USA & Mar-May & Not found \\
\hline Brussels Flower Carpet & Brussels/Belgium & Aug & Not found \\
\hline $\begin{array}{l}\text { Gardens of England and Wales Open for } \\
\text { Charity }\end{array}$
\end{tabular}

* Estimated. Multiple sources

\section{RHS Chelsea Flower Show}

Chelsea Flower show is a promotion of the Royal Horticultural Society (RHS), which has been performed every year, since 1862. This show Garden is held at the Royal Hospital Chelsea, London/England, and demonstrates the best of horticulture and garden design, being a source of ideas and trends, inspiring gardeners, landscapers, and people. Chelsea Show is one of the most prestigious flower shows in the world, receiving every year the attendance of several members of the British Royal Family as part of the royal patronage of the RHS (https://www.rhs.org.uk/ shows-events/rhs-chelsea-flower-show).

\section{Expoflora}

Expoflora is the largest flower and ornamental plant exhibition of Latin America, and is held in Holambra city, Brazil (Figure 3). During almost one month, in spring time, visitors have a chance to learn about new varieties and cultivation techniques, besides the contact with Holland culture (Expoflora, 2020).

\section{Keukenhof}

Keukenhof is an international showcase promoted by the Dutch floricultural sector, performed every year in springtime at Lisse (The Netherlands) (https://keukenhof.nl/en/). In the park, designed in English landscape style, around 7 million flower bulbs donated by growers are cultivated annually. The bulb species are planted in flowerbeds designed in different shapes and in combinations of plants and colors, allowing the visitors an impressed view (Figure 3).

\section{Garden Festivals}

Garden festivals should be a remarkable experience through the eyes of the visitors. Worldwide there are many garden festivals, but some have become more famous over time.

One of them is organized by The National Trust at Germany being a national charity focused on the conservation of buildings and landscapes. It aims to preserve spaces, to protect wildlife and heritage. For every two years, a garden festival is performed in a different city, the Bundesgartenshaus or BUGA, and millions of visitors have a chance to attend (National Trust, 2020).

The most famous festival worldwide and a successful model of promoting tourism through gardening is the Chaumont-sur-Loire Garden Festival held annually in France (Figure 3). This International Garden Festival aims to function as a laboratory for contemporary garden and landscape design (http://www.domaine-chaumont.fr/en/ international-garden-festival). Annually, exhibitors built demonstrated gardens, trying plants and objects in different combinations and design. 

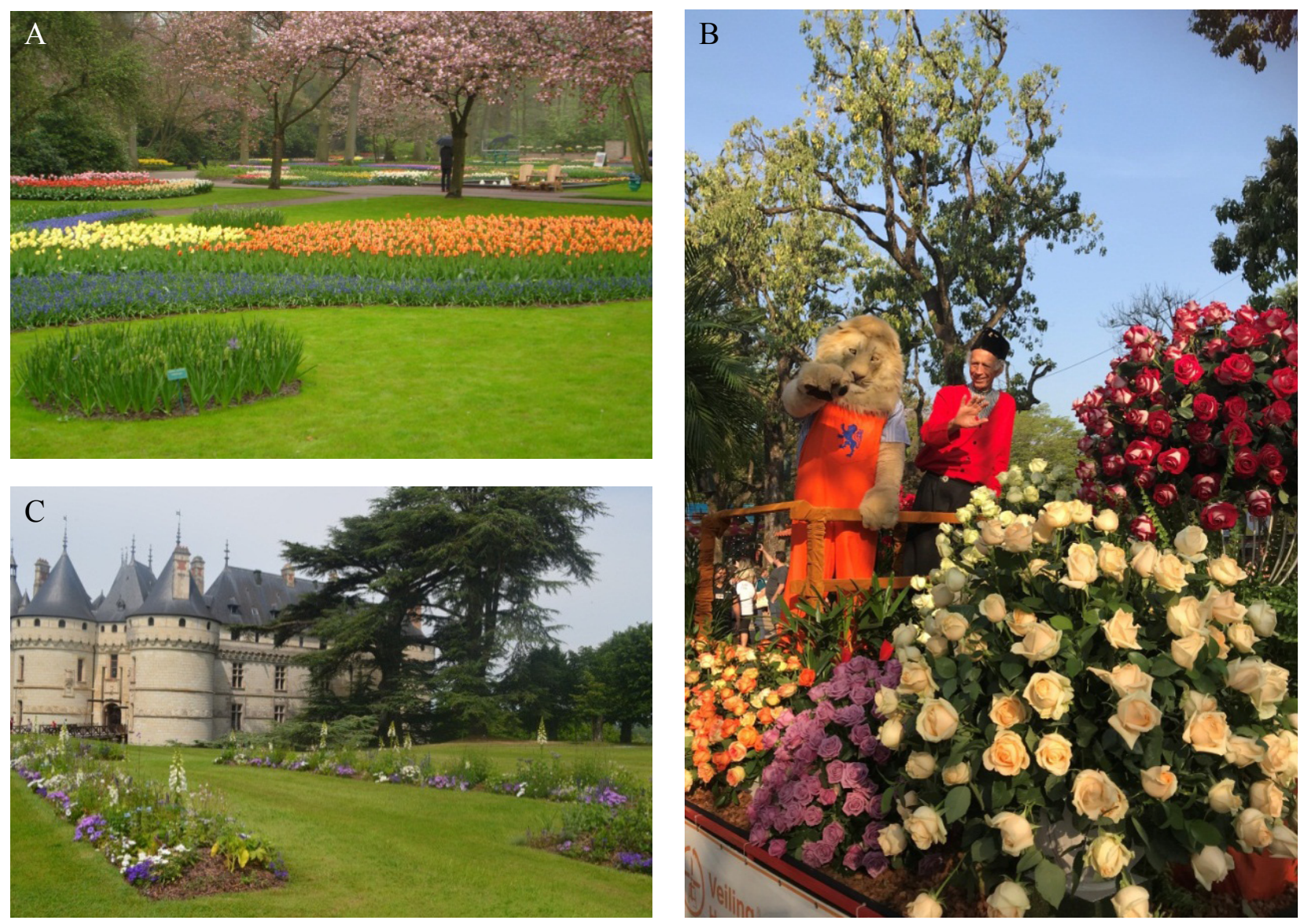

Figure 3. A) Keukenhof (The Netherlands) B) Expoflora (Brazil).

C) Garden Festival of Chaumount-sur-Loire (France)

Ponte de Lima (Portugal) is now considered a fashionable touristic destination, mainly due to the Garden Festival, turning the city a reference in garden tourism. The Garden Festival of Ponte de Lima was created in 2005, having as a model, the Garden Festival of Chaumont-surLoire (Rodrigues, 2015).

The Epcot International Flower \& Garden Festival is a recent event with the first one performed in 1995, but only since 2015 it takes place every year, during springtime in Orlando (USA) (https://disneyworld.disney.go.com/pt-br/ events-tours/epcot/). The main attraction of this festival is the Disney characters' topiaries displayed in the flower gardens, whose number has increased every year.

In a garden festival, a very good solution to involve the community and visitors is to give them the right to vote for their favorite garden. For exhibitors, it gives them visibility and the possibility to participate in the following year (Rodrigues, 2015).

\section{Trail gardens}

Trail gardens are some annual exhibitions generally performed by universities or research centers that attract the local and regional public. Mainly held in springtime, the public has a chance to explore new varieties of ornamentals as perennials, annuals, besides vegetables, and give their impression, by evaluating and indicating the most attractive in their mind. As result, in one side, it helps the horticultural industry indicating the performance of the new varieties, and recognizing the most acceptable new varieties and, on other hand, people are stimulated to plant and grow species in different combinations. Some famous events are performed at the Michigan State University (https://www.canr.msu.edu/hrt/our_gardens/trial_garden); University of Georgia (https://ugatrial.hort.uga.edu/), and at The Ohio State University (https://ohiofloriculture.osu. edu/cultivar-trials).

\section{Other Gardens for visitation}

\section{Memorial Gardens}

Memorial garden is a place built with specific purposes, as remarkable histories, to remember someone or something special. Normally, a garden is planted as a tribute to lives that were lost. In this type of garden, trees, shrubs, and 
flower beds maybe planted, within structures as sculptures, stones, and/or watercourse. Visiting these gardens turn possible to keep alive fact memories and people. Some examples are the Memorial September 11, built in New
York City, and Pentagon Memorial in Washington, both in the USA, built in memory of the victims of the September 11 terrorism attack; and the Giardini dei Giusti del Mondo at Padova (Italy), remembering the holocaust victims (Figure 4).
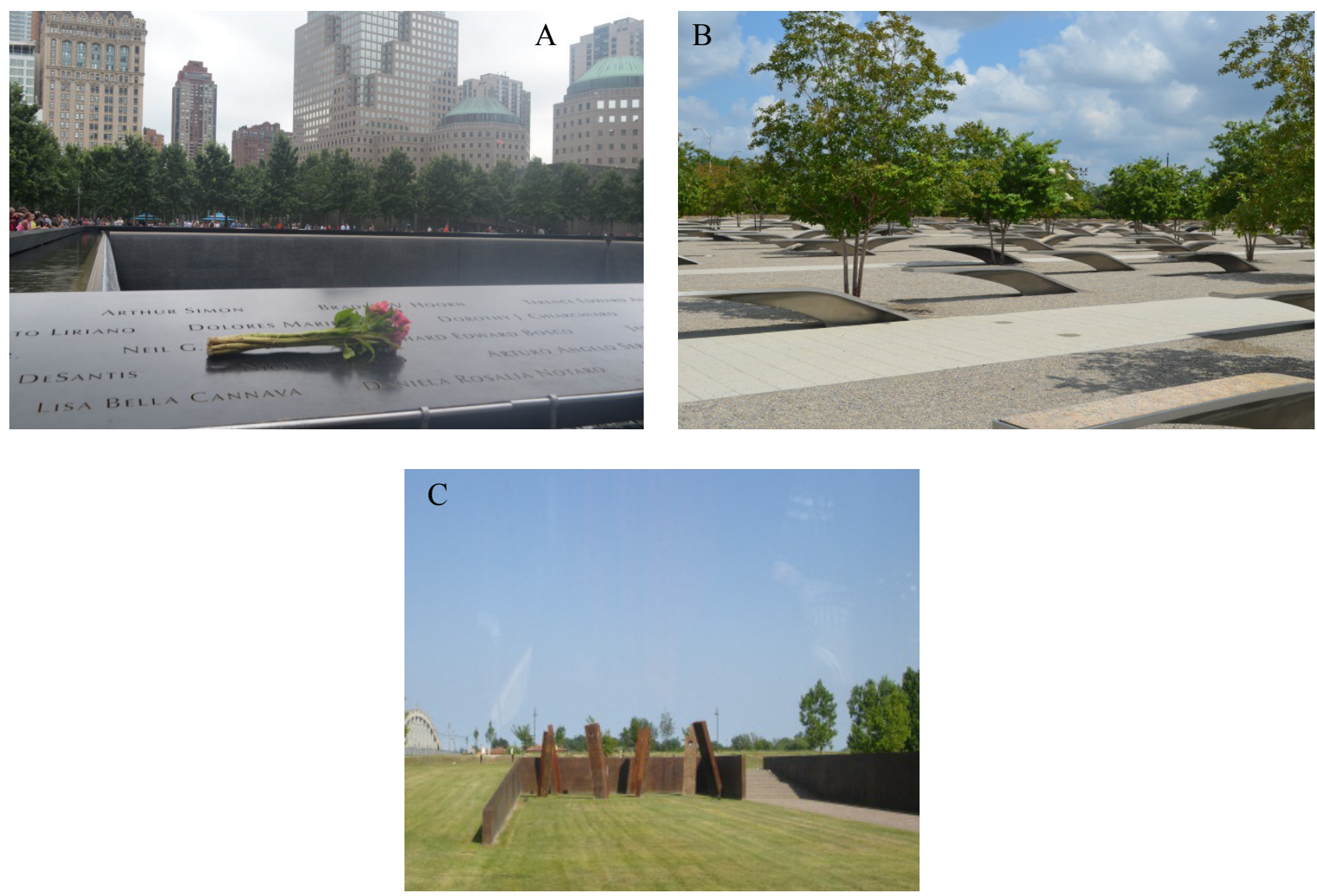

Figure 4. Memorial Garden. A) Memorial September 11, New York-USA. B) Pentagon Memorial, Washington-USA. C) Giardini dei Giusti del Mondo, Padova-Italy.

\section{Cemetery/Graveyard}

Although it is not a real pleasant place to visit, a garden in these places turns the atmosphere more agreeable. Planting a garden is also a way to honor and keep alive the past and history. One of the most visited cemetery is the Green-Wood Cemetery in New York (USA) which attracts not only the Revolutionary War buffs but also birdwatchers (Grindell, 2019).

\section{Religious gardens}

Distinctly of sacred places, religious gardens are places built to allow religious celebrations or simply to be a silent place for prayer. Some examples are the Caminho do Rosario [Rosario Way] in Aparecida do Norte city (Brazil) or the Way of the Cross in Monserrate Sanctuary, Bogotá
(Colombia). Both, gardens exhibit sculptures remembering Biblical history and facts.

\section{Rural Tourism}

In a rural Garden Tour, visitors are looking for an ordinary garden, where there are more than plant arrangements and ornamental vases. The visitor may smell the fragrances, listen bird's song and watercourses, as well as feel the countryside life by cultivating vegetables, tea plants, and orchards, besides being part of the family costumes as a coffee or tea time (Cauquelin, 2005; Petry, 2013). According to the owners, built an ordinary garden requires patience, attempt, and experimentation. In their view, there is the conscious that they are dealing with a "living being" (Clemant, 2012). 
One example of this is the Rural Garden Tour on farms nearby Victor Graeff city, Rio Grande do Sul State, Brazil. Visitors may set a day or half-day tour in some small farms. The owner makes the reception and the visitors have the opportunity to know gardens, plants, propagation and in the end, they have a lunch or coffee with the family farm.

Visiting Lavender's farms are another specific, but famous rural garden option. Although the most famous in the world is the Provence region in France, there are also some small places like Cunha (Brazil) or Lyndoc (Australia). In these places, visitors may walk around and take amazing photos in Lavender cultivation, besides feel the aroma and flavors in a cafeteria, and buy lavender' souvenirs on shops.

\section{Rose Garden}

In some gardens, a special place has been created and destined to rose cultivation. Many rose species, with distinct growth habits, are cultivated in these areas. Generally opened for visitation in springtime, rose gardens receive many visitors, attracted by the colors, shapes, and aromas of these flowers. Some examples are the Queen Mary's Rose Garden in Regent's Park in London (England) and El Rosedal de Palermo in Buenos Aires (Argentina). Also, these places are used for the maintenance of plant collections, supporting researches, and spreading de knowledge, since is it possible to see ancient cultivars, as there are on the Nikita Botanical Garden (Russia) or at the Padova Rose Garden (Italy).

\section{Museum Gardens}

At some museums, gardens are not only a complement but a great attraction, turning into a scenario for artworks (Bianchini, 2017). In some situations, galleries and gardens are displayed around the builds or as part of the visitation like the Adachi Museum in Japan, the Qualy Branly Museum and the Jardin des Plantes of the Musée National d'Histoire Naturelle, both in Paris, France. But in a true Museum Garden, gardens are scenery for the exhibitions. One example is the Rodin Museum in Paris, France, in which the collection of famous sculptures by Auguste Rodin is displayed in a classical French Garden style. Another one is the Crystal Bridges in Bentonville, Arkansas (USA), where ancient and contemporary art is associated with nature, in galleries and halls, all inside a forest.

\section{Conclusions}

Overall and to conclude, the French landscaper Gilles Clément offers a very good analysis of the importance of a garden in society (Clément, 2013):

"The garden is an enclosure and a paradise. Within this enclosure, the gardener (or the King - as the owner) protects what consider to be the best, the most precious, the rarest, but also the most clear from the mature throught of the time when the garden was designed (...)

Over time, the style of the garden changes since the message changes: the idea of the "best» was not the same as during the Renaissance, or the 18th century, or the dawn of romanticism. (...). The gardens by Le Nôtre (...) place the human freed from his subjugation to nature, as the son of Prometheus, regulating the conditions of his living space to express in all glory, by a fabulous scenography, the absolute mastery of the living one. And leaving the nature as a hunting territory in a woodland intersection. Today's gardens, which cannot escape of the ecological consciousness, and place the livings not human at the heart of the space to be protected, relegating human to a place of an attentive observer, at best of gardening.»

\section{Acknowledgments}

Authors are thankful to $\mathrm{CNPq} / \mathrm{Brazil}$ and FAPEMIG/Brazil for the financial support and scholarship for the research on development of Historic Gardens.

\section{Author Contribution}

P.D.O.P. ${ }^{0000-0001-7997-8420}$ : idea, literature review, research, text writing, and manuscript review; also took all the photos. R.B.S.: literature review, research, text writing, and manuscript review. N.C.: literature review, research, text writing, and manuscript review.

\section{References}

ALVES, S.F.N.S.C.; FIGUEIREDO, M.A.; PAIVA, P.D.O. História da Praça Gomes Freire - O jardim de Mariana. Lavras: Editora UFLA, 2010 (Coleção Praças da Estrada Real. Série Cidades Históricas, 1).

ANDRADE, I. E-J. Construção e desconstrução do conceito de jardim histórico. Risco: Revista de Pesquisa em Arquitetura e Urbanismo, v.8, p.138-144, 2008.

BACKHAUS, G.; MURUNGI, J. Symbolic Landscapes. Springer, 2009. 420p.

BENNETIERE, M.-H. Jardin - vocabulaire typologique et technique. Principes d'analyse scientifique, sous la direction de M. Chatenet et M. Mosser, Editions du patrimoine, 2000, Préface pp.10-13.

BIANCHINI, R. Museum gardens - when the garden is an exhibit, 2017. Available at: https://www.inexhibit.com/ case-studies/gardens-museums-gardens-exhibits/ Accessed on: January 12, 2020.

BRIGAND, J.P. Economic factor of garden tourism. In: RODRIGUES, A.D. (ed). Gardens and Tourism - for and beyond economic profit. CHAIA/CIUHCT, 2015. p.135-146.

CAUQUELIN, A. Petit traité du jardin ordinaire. Paris: Payot \& Rivages. 2005. 206p. 
CAMARGO, H. L. Uma pré-história do turismo no Brasil. Recreações aristocráticas e lazeres burguês (18081850). São Paulo: Aleph, 2007.

CATAHAN, N.; WOODRUFFE-BURTON, H. The view, brew \& loo: perceptions of botanic gardens? Journal of Place Management and Development, v.12, n.1, p.20-38, 2018.

CIBINSKIENE, A.; SNIESKIENE, G. Evaluation of city tourism competitiveness. Procedia - social and Behavioral Sciences, v.213, p.105-110, 2015.

CLAVAL, P. Parcs et jardins. BAGF-Bulletin de l'Association de Géographes Français, n³, p.167-175, 1989.

CLÉMENT, G. Jardins, paysage et génie naturel. Paris: Collège de France/Fayard. 2012. 68p.

CLÉMENT, G. Le Nôtre - il y a 4 siècles naissait le roi des jardiniers. Télérama Hors-série, 2013, pp.93.

CONNELL, J. The purest of human pleasures: the characteristics and motivations of garden visitors in Great Britain. Tourism Management, v.24, n.2, p.229 -247, 2004. https://doi.org/10.1016/j.tourman.2003.09.021

CONNELL, J. Managing gardens for visitors in Great Britain: a story of continuity and change Tourism Management, v.26, p.185-201, 2005. doi:10.1016/j. tourman.2003.10.002

DOOLITTLE, W. Gardens are us, we are nature: Transcending antiquity and modernity. The Geographical Review, v.94, n.3, p.391-404, 2004.

EDWARDS, C.E.; WYSE JACKSON, P. The development of plant conservation in Botanic Gardens and the current and future role of conservation genetics for enhancing those conservation efforts Molecular Frontiers Journal, v.3, n.1, p.44-65, 2019.

EXPOFLORA. Informações Gerais Expoflora. Available at: https://www.expoflora.com.br/informacoes-geraisexpoflora/Access on: January 10, 2020.

FALLAHI, E. Horticulture in Iran can be an alternative to petroleum and a major source of international business with unique potential and challenges. HortScience, v.52, p.1145-1147, 2017.

FALLAHI, E.; FALLAHI, P.; MAHDAVI, S. Workshop: Ancient Urban Gardens of Persia: Concept, History, and Influence on Other World Gardens. HortTechnology, p.17, 2019. https://doi.org/10.21273/HORTTECH04415-19
GARCIA, C.S.G.; ALVES, S.F.N.S.C.; PAIVA, P.D.O. História do Jardim da Avenida Tancredo Neves: A praia de São João Del-Rey. Lavras: Editora UFLA, 2011 (Coleção Praças da Estrada Real. Série Cidades Históricas, 3).

GARCIA, C.S.G.; PAIVA, P.D.O; ALVES, S.F.N.S.C.; SALGADO, M.C.R. Transformations in the gardens and landscapes of the historical Traituba's Farm. Ornamental Horticulture, v.23, n.1, p.45-57, 2017.

GASTAL, S.; BEBER, A.M.C.; CÉSAR, P.A.B. Garden tourism e jardins históricos: a natureza patrimonializada. International Journal of Scientific Management and Tourism, n.4-3, p.109-119, 2018a.

GASTAL, S.; ROCHA, V. CASTROGIOCANNI, A.C. Jardins botânicos e turismo de jardins: pesquisa de audiência em Porto Alegre e Caxias do Sul, RS. Caderno Virtual de Turismo, v.18, n.1, p.170-186, 2018b. http:// dx.doi.org/10.18472/cvt.18n1.2018.1314.

GRINDELL, S. 19 beautiful cemeteries that might change your outlook on death. Insider, 2019. Available at: https://www.insider.com/most-beautiful-cemeteries-inthe-world. Accessed on January 12, 2020.

HEYWOOD, V.H. The future of plant conservation and the role of botanic gardens. Plant Diversity, v.39, p.309-313, 2017.

ICOMOS. Historic Gardens - The Florence Charter, 1981. Paris: International Council on Monuments and Sites. 1982. https://www.icomos.org/en/newslettersarchives/179-articles-en-francais/ressources/charters-andstandards/158-the-florence-charter

JOHN EVELYN, 2020. Available at: https://en.wikipedia. org/wiki/John_Evelyn. Accessed on: January, 2020.

KEMPIAK, J.; HOLLYWOOD, L.; BOLAN, P.; MCMAHON-BEATTIE, U. The heritage tourist: an understanding of the visitor experience at heritage attractions. International Journal of Heritage Studies, v.23, n.4, p.375-392, 2017. 7 http://dx.doi.org/10.1080/13 527258.2016 .1277776

KRISHNAN, S.; NOVY, A. The role of botanic gardens in the twenty-first century. CAB Reviews, 2016, n.023. Doi: 10.1079/PAVSNNR201611023

LEIPER, N. Tourist attraction systems. Annals of Tourism Research, v.17, n.3, p.367-384, 1990.

LOUIS XIV. Manière de Montrer les jardins de Versailles. Paris: Artlys, 2013. 55p. 
LUZ, I.C.A.; PAIVA, P.D.O. História da Praça Dr. José Esteves - a Praça da Estação de Lavras. Lavras: Editora UFLA, 2017. (Coleção Praças da Estrada Real. Série Caminhos dos Bandeirantes, 3).

MCC - Ministére de la Culture et de la Communication. Actions en faveur des jardins. Ministere de la Culture et de la Communication, 2012. Available at: www. rendezvousauxjardins.culture.fr.

McMILlAN, A.M.; PLUMPTRE, G. National open Garden Scheme - Impact report 2019, 22p. Available at: https://ngs.org.uk/wp-content/uploads/2019/12/ImpactReport-2019-1.pdf

MICHEL DE MONTAIGNE, 2020. Available at: https:// en.wikipedia.org/wiki/Michel_de_Montaigne). Accessed on January 5, 2020.

MILLER, A. J.; NOVY, A.; GLOVER, J.; KELLOGG, E.A.; MAUL, J.E.; RAVEN, P.; JACKSON, P.W. Expanding the role of botanical gardens in the future of food. Nature plants, v.1, n.6, p.1-4, 2015.

MONTPELLIER. Les jardin des Plantes. Available at: https:// www.montpellier-france.com/offre/fiche/le-jardin-desplantes/PCULAR0340000107. Access on: January 10, 2020.

NASCIMENTO, A.M.P.; PAIVA, P.D.O. História da Praça Barão de Queluz- O caminho para o ouro em Conselheiro Lafaiete. Lavras: Editora UFLA. 2012 (Coleção Praças da Estrada Real. Série Caminhos dos Bandeirantes, 2).

NATIONAL TRUST. Buga. Available at: https://www. nationaltrust.org.uk/. Accessed on: January 10, 2020.

NIKOL, T.; JUKES, S. Travel \& Tourism - a force for good in the World. UnitingTravel, 2018. 31p.

PAIVA, P.D.O. Paisagismo - conceitos e aplicações. Lavras: Editora UFLA, 2008. 608p.

PAIVA, P.D.O.; ALVES. S.F.N.S.C. História da Praça do Campus histórico da UFLA - aqui nasceu a universidade. Lavras: Editora UFLA, 2011. 43p.

PETRY, C. Roteiro de Jardins Rurais em Victor Graeff, RS, Brasil: Jardinistas por vocação! Ou ... a metamorfose das agricultoras. Revista Brasileira de Horticultura Ornamental, v.19, n.1, p. 35-46, 2013.

PORIA, Y.; BUTLER, R.; AIREY, D. Links between tourists, heritage, and reasons for visiting heritage sites. Journal of Travel Research, v.43, n.1, p.19-28, 2004.

POWLEDGE, F. The evolving role of botanical gardens. BioScience, v.61, n.10, p.743-749, 2011.
RENDEZ-VOUS AUX JARDINS, 2020. Available at: https://www.parcsetjardins.fr/actualites/manifestationsnationales/rendez-vous-aux-jardins-2020-1449. Access on: March $17^{\text {th }}, 2020$.

RICHARDS, G. The Experience Industry and the Creation of Attractions. In: RICHARDS, G. Cultural Attractions and European Tourism, Oxfordshire: CABI Publishing, 2001, p.55-69.

ROCHA, Y. T.; CAVALHEIRO, F. Aspectos históricos do Jardim Botânico de São Paulo. Revista Brasileira de Botânica, v.24, n.4, p.577-586, 2001.

RODRIGUES, A.D. The Festival Garden at Pont de Lima: a case of success. In: RODRIGUES, A.D. (ed). Gardens and Tourism - for and beyond economic profit. CHAIA/CIUHCT, 2015. p.63-78.

SILVA, S.; CARVALHO, P. Os jardins históricos: da dimensão patrimonial ao seu potencial turístico. Turismo \& Sociedade, v.6, n.3, p.605-625, 2013.

SILVA, S.; CARVALHO, P.; TOMÁS, P.M.C. Os jardins no contexto do turismo pós-moderno. O caso de Portugal. Pasos - Revista de Turismo y Patrimônio Cultural, v.11, n.4, p.631-647, 2013.

SMITH, P. Growing public engagement impact: opportunities and challenges for botanic gardens. Botanic Gardens Conservation International (BGCI), 2018. Available at: https://www.bgci.org/wp/wpcontent/uploads/2019/07/Smith-Paul-Growing-publicengagement-impact.pdf. Accessed on: January 10, 2020.

SOUSA, R.B.; PAIVA. P.D.O; FERRAZ, R.M. História da Praça João Pinheiro - o Largo da Cavalhada no Serro, Lavras: Editora UFLA, 2017 (Coleção Praças da Estrada Real. Série Cidades Históricas, 6).

UNESCO. What is world heritage? 2020. Available at: https://whc.unesco.org/en/faq/19. Accessed on January 13, 2020.

UNWTO - United Nations World Tourism Organization, 2020. Available at: https://www.unwto.org/. Accessed on: January, 2020

WTTC - World Travel \& Tourism Council. Economic Impact. Available at: https://www.wttc.org/economicimpact/. Accessed on: December, 2019.

WYSE JACKSON, P.S. Experimentation on a large scale - an analysis of the holdings and resources of botanic gardens. Botanical Gardens Conservation News, v.3, n.3, 1999. 